\title{
THE INFLUENCE OF USING TIME TOKEN METHOD TOWARD SPEAKING ABILITY AT THE STUDENTS' OF SMP N 1 BATANGHARI ACADEMICYEAR 2014/2015
}

\author{
Retno Fentari \\ retnofentari@ rocketmail.com \\ Syaifudin Latif D \\ Latifdar2011@gmail.com
}

\begin{abstract}
:
The objective of the study is to know whether there is influence of Time Token method toward students' speaking ability. The research design of this research is Quantitative Design. The population of this research is 625 students. It consists of 21 classes and average of each class consists of 32 students. The researchers conducted the research at the eighth grade of SMP N 1 Batanghari. The researcher took 64 students from the total population as the sample. This research takes two classes: they are experimental class and control class. In Colleting the data, the researcher used test. The test comprised two tests: pre test and post test. To analyze data, the researcher used $t_{\text {test }}$ formula. The result of the study showed that $t_{\text {count }} 5,37$ and $t_{\text {daf }}$ is 2,00 (on criteria1) and 2,66 (on criteria 2). It means that $t_{\text {count }}>t_{\text {daf. }}$. And the criteria of $t_{\text {count }}$ is $H_{a}$ accepted if $t_{\text {count }}>t_{\text {daf. }}$.
\end{abstract}

Key Words: Time Token Method, Speaking Ability

\section{INTRODUCTION}

Speaking is one of the skills that have to be mastered by students in learning English. Speaking is an essential tool for communicating. Hornby (1995, p.37) defines that speaking is the skill that the students will be judged upon most in real-life situations. It is an important part of everyday interaction and most often the first impression of a person is based on his/her ability to speak fluently and comprehensively.

In a Speaking class, students are expected to participate actively. The more students participate, the better their speaking ability will be. However, many educators regretted the fact that Speaking classes are very quiet. Students do only 
speak when they are asked by the lecturers. Besides, only few of them are willing to answer the questions voluntarily without being asked to. More students have to speak when they are finally pointed by the teacher to answer. Being forced in that way, students answer the questions doubtfully and in a muffled voice, almost inaudible by other students.

There is only one interaction pattern, example, from the teacher to the students. If the students are invited to draw questions and express their ideas, most of them will bow their heads and say nothing.

Based on the syllabus at eighth grade, for speaking competence; (1) Students have to understand the transactional conversation in daily life context, (2) Students can express the meaning in short functional text in context daily activity, and (3) Students are able to identify simple monolog in form descriptive text. So, as teachers, we have a responsibility to prepare the students as much as possible to be able to speak in English in the real world outside the classroom. And the teacher expects the students to be able to use English.

Based on the pre survey the researcher found some students' problems in speaking at SMP N 1 Batanghari; (1) students had difficulty to express their thought orally; (2) students weren't confident with their capability, so they seldom use English in their daily activity; (3) students weren't interested in English subject because English difficult. They through that were than the researched did pre-test. The result was as follow:

\section{Table 1.1 Pre Observation Data of Students Speaking Ability}

\begin{tabular}{|c|l|l|l|l|}
\hline No. & Score & Category & Score & Presentation \\
\hline 1 & $81-100$ & Highest & 6 & $10 \%$ \\
\hline 2 & $61-80$ & Middle & 8 & $25 \%$ \\
\hline 3 & $<60$ & Lowest & 18 & $65 \%$ \\
\hline & & Total & 32 & $100 \%$ \\
\hline
\end{tabular}

Source : The Observation toward English Learning at SMPN 1 Batanghari Academic Year 2014/2015

Furthermore, based on the pre-test there were about $65 \%$ students have low score in speaking ability. It means that majority of students have the low ability in speaking. And then the students who got score in medium level are noted about $25 \%$ and the last, there were about $15 \%$ of students in high level. This 
fact is still far from what hoped and it needs the ways to change to the better one. This fact is happened because the technique that be used by the teacher was not interesting to the students. So, it is necessary for English teacher to make the speaking teaching more interesting and to motivate the students.

Considering the explanation above, in this research, the researcher would like to focus on the influence of using Time Token method toward students' speaking ability at the eighth grade of SMP N 1 Batanghari Academic Year 2014/2015.Based on the problem background, the problems of the study can be formulated as follows; Is there any influence of Time Token method toward students' speaking ability at the Eight Grade of SMP N 1 Batanghari Academic Year 2014 / 2015?And based on the problem formulation above, the objectives of this research are; To know whether there is influence of Time Token method toward students' speaking ability at the eighth grade of SMP N 1 Batanghari academic year 2014/2015.

There are some literature overviews which make the researcher interested to do this research. The first previous research overview from Fatmawati (2011) and the title is "The effectiveness of Time Token Arends Strategy Toward Reading Comprehension in Travelling Report in Eight Grade SMP N Wonosari Gunung Kidul. "The time of research was 2011.

A practical research, which includes explain that time token strategy is effective for reading comprehension. Furthermore, the strength of this research is time token strategy able to achieve reading comprehension and the average of the students has achieving in scoring of reading comprehension in travelling report. Moreover, time token methods are able make student active, creative, collaborative, competitive, and cooperative. In other hand, there are some weaknesses of this research.

The second is the researcher overview from Firmansyah (2011) with the titles "The Comparison of Five Fingers Method and Audio Lingual Method toward Student's Speaking Ability at SMK Muhammadiyah 2 Metro Academic Year 2010/2011."This practical research are explain applying the two methods students are expected to be able to speak confidently, pronounce the English word 
and along with the form of the sentence well. Furthermore, the strength of this research is five fingers method and audio lingual method find that students are able to imitate pronounce and to form the sentences well. Five fingers method finds that students are able to pronounce and to form the sentences well and audio lingual method find that the students are able to imitate pronounce and to form the sentences well. The researcher concludes that two methods can achieve speaking ability in conducting teaching learning method so that the students can interest in studying.

The difference between those two previous researches with this research are, sample and the variable. The title of this research is the Influence of using Time Token Method toward Students' Speaking Ability at the Eighth Grade of SMP N 1 Batanghari Academic year 2014/2015.

Concept of Time Token Method is explained as follow. According to Arends (2008,p. 29), that Time Token Method is a cooperative learning model used to develop the skills of participation of learners. Strategy Time Token Method introduced by Arends. This strategy is one type of active learning strategies that can be applied in the classroom.

Moreover according to Fatmawati (2011,p.20), Time token is one of method which can help the students to achieve speaking skill. Time Token Arends learning model is one small example of the application of democratic learning in school. Democratic learning process is a learning process that puts students as subjects. This model is used to train and develop that social skill student does not dominate talk or silent absolutely. This method is a teaching model that can be used for teaching student to achieve their skill and showing opinion and scoring task of their friends. This model planned that the student should speak and get social with each other.

From the statements above, it can be concluded that time token method has suitable learning structure used for teaching social skill, and avoid students dominate speaking or silent absolutely in the class. They shall experience a chance to be more positive course. 
Concept of Speaking Ability is also elaborated as follow. Speaking is one of the skills that to be mastered by students in learning English. Many experts defined speaking in different ways. Bryne in Oktaviani (2012,p. 13) states that Speaking is as a two-way process between speaker and listener and it involves the productive skill and receptive skills of understanding. Moreover Thornbury (2005,p.1) Speaking is like writing and that a speaker produces a distinctive pattern or energy much like typewriter produces letters, for every distinct vowel and consonant that we perceive. While according of Hughes in Saputra (2012,p.12), "Speaking is important aspect in language learning. By speaking, they can convey information, ideas, and maintain social relationship by communicating with other".

There are some aspects to evaluate the students speaking ability. It is important to be known by the speak. The aspects are as follow: Pronunciation, vocabulary, grammar, fluency, and comprehension.

Based on the explanation above, it can be concluded that speaking is important aspect in language learning. By speaking, they can convey information, ideas, and maintain social relationship by communicating with other. So, It can also influence human's mind, so that listener has the some thought is not only and expression of thinking to make someone understand but also change behaviour.

Concept of Teaching Speaking according to expert varies. According to Hornby $(1995$, p.37) teaching means giving the instruction to a person, give a person knowledge skill, etc. In learning a foreign language, speaking is very important. The goal of teaching a second or foreign langua ge is to gain the ability to communicate in the target language (Mabrur, 2002,p.8). Therefore the teacher should give the students' opportunity to use the target language to communicate with others. The teacher could use the speaking class to improve the students' speaking ability. And it can be an effective way for the teacher to know whether the students active in class or not.

Thinking Framework of this research is described below. Based on explanation above, time token method can achieve reading comprehension and general chemistry. In this research, the researcher would like use time token 
method towards students speaking skill in English learning. Furthermore, the advantage of time token method forces the student to speak and develops that social skill student does not dominate talk or silent absolutely. It makes the average score will be higher than before using that method. It will make student practice to speak up. Furthermore, the students will more interaction with their friends through discussion. They will share everything to their friends when they speak and it will develop their skill in speaking. It means that their friend can help to motivate their speaking skill through time token method. So, there is influence of using time token method towards speaking ability.

\section{RESEARCH METHOD}

Research design that will be used in this research is quasi experimental design. Sugiyono (2010,p. 112) states the characteristic of quasi experiment design is the sample which is used for experiment group or control group are taken by using random technique from certain population. In this design, there are two groups are chosen by cluster random sampling technique.

\section{Population, Sampling Technique and Sample}

The population of the research is all of students of SMP N 1 Batanghari. They are VII, VIII, and XI. The total number of population is 625 students. In this research, the researcher will take of two classes of the eighth grade of SMP N 1 Batanghari academic year 2014/2015 as the sample. The researcher uses cluster random sampling technique. This sampling will be used by researcher in order to define the level of class that becomes the experiment and control classes. And finally, the researcher got VIII $b$ is experimental class and VIII $d$ is control class, by (Sugiyono, 2010,p.118).

To collect the data the researcher use pre-test, treatments, and post-test. The test is done at SMP N 1 Batanghari. The method of collecting data is written with the test item instrument. After giving the test and finding the result of the test, student's score pre-test and post-test will be taken by using normality test, homogeneity test, and hypothesis test. 


\section{Validity and Reliability of Instrument}

The validity and reliability of instrument will be explained by the researcher, as follow:

\section{Validity Instrument}

The validity means a tool of measurement which used to get data validity (Sugiyono, 2011,p.172). It is supported by Gay (1990,p. 128) that validity is the degree to which a test measures what it is supposed to measure. From the two statements mean that the test can be said valid if the test is quite representative materials that are given.

Content validity occurs when the experiment provides adequate coverage of the subject being studied. To maintain the validity of the data, in this study used content validity. This includes measuring the right things as well as having an adequate sample. Samples should be both large enough and be taken for appropriate target groups. The test item is given to measure or test the student's speaking ability. To know whether the test is valid or not, the instrument has to get validation from the expert judgement. The expert judgements are Refai,S.Pd. M.Pd, and Amirudin Latif, S.Pd., M.Pd.

\section{Reliability of Instrument}

According to Arikunto (2010, p.221) the reliability of the test is an instrument can be believed to be used as instrument for collecting data because it has been good. It means that the test has some average result when it is tested to different occasion and the condition is the same as before.

The researcher uses inter-rater reliability. Inter-rater reliability in accounted from the two rows of score which is gotten from two correctors. In inter-rater reliability, the scoring can be done equally. Where, the students' speaking performance can be evaluated equally by two correctors. Because the test is corrected by two correctors, generally the result of reliability test can be reliable. The inter-rater reliability can be counted by using Pearson Productmoment like as bellow: 


$$
r_{x y}=\frac{\sum_{x y}}{\sqrt{\left(\sum_{x^{2}}\right)\left(\sum_{y^{2}}\right)}}
$$

(Adopted from Creswell, 2010)

Notes:

$$
\begin{array}{ll}
r_{x y} & =\text { The coefficient correlation between } \mathrm{X} \text { variable and } \mathrm{Y} \text { variable. } \\
x & =\text { The score of test } 1 \\
y & =\text { The score of test } 2 \\
x^{2} & =\text { Deviation } \mathrm{X} \\
y^{2} & =\text { Deviation } \mathrm{Y} \\
\sum x y & =\text { The score of } \mathrm{x} \text { and y product }
\end{array}
$$

\section{Normality Test}

Normality test are used to determine whether a data set is well modelled by a normal distribution or not. In normality test, the researcher finds out each score of distribution of Expected Frequency and Perception Frequency and the formula that can be used is as follow:

$$
X_{\text {ratio }}^{2}=\frac{\left(O_{i}-E_{i}\right)^{2}}{E_{i}}
$$

(Adopted from Ahmad, 2011,p. 31)

\section{Homogeneity Test}

Homogeneity is a measurement used to determine data variety. The formula of homogeneity test is as follow:

$\mathrm{F}_{\text {ratio }}=\frac{\text { the bigest variance }}{\text { the smallest variance }}$

\section{Hypothesis Test}

When the sample comes from the population which in distributed normally and homogeneously, the test will be continued to the hypothesis test. The hypothesis test can be measured by t-test with the formula as follow; 
$t_{\text {ratio }}=\frac{x_{1}-x_{2}}{S_{g} \sqrt{\frac{1}{n_{1}}+\frac{1}{n_{2}}}}$

Where: $S_{g}^{2}=\frac{\left(n_{1}-1\right) S_{1}^{2}+\left(n_{2}-1\right) S_{2}^{2}}{n_{1}+n_{2}-2}$

Notes:

$x_{1} \quad$ : The arithmetical mean of

experiment group

$x_{2} \quad$ : The arithmetical mean of

control group

$n_{1} \quad$ : Number of students in

experiment group

$n_{2} \quad$ : Number of students in

control group

$S_{1}^{2} \quad:$ Standard deviation of

experiment group

$S_{2}^{2} \quad$ : Standard deviation of

control group

\section{RESULT}

After getting the result of validity instrument, the researcher calculated the data of try out using Product Moment formula to know its correlation, and from the calculation result, the researcher got score 0,99 for the correlation between rater I and rater II. After that, to get the reliability of the instrument of test, the correlation result was calculated using Spearman Brown formula. From the calculation, it was obtained the result of the test was 0,99 ; and based on criteria of prediction index reliability, it has very high reliability. It means that the instrument of test can be used in this research.

After researcher got the result of validity and reliability of the instrument, the researcher conducted the pre-test. The function of pre-test is to know the students' achievement in speaking ability before giving treatment. And from the pre-test, the researcher found that in experiment class, the highest score of pre-test was 68 , and the lowest score was 28 ; whereas in control class the highest score was 60 and the lowest score was 32. After that the researcher conducted the posttest. The post test was administered after treatment. The post test was administered in order to see the significance of students' speaking ability using Time Token Method. Then after getting the result of the data of post-test, the researcher found that in experiment class the highest score was 80 and the lowest 
score was 52; whereas in control class the high score of post test was 72 and the lowest score of post-test was 44 .

By using the pre-test and post-test data, the researcher could continue the calculation to find out the normality and homogeneity of test. The normality was employed to know whether that test come from the population have the normality distribution or not. Based on the calculation it was obtained that $x_{\text {Count }}^{2}$ of pretest and post-test of experiment and control class were lower than $x_{d a f}^{2}$ for the significance level of $5 \%(\alpha=0.05)$ and also $1 \%(\alpha=0.01)$ in the reality. It means that both samples in this research come from the population that has normal distribution. Then homogeneity of test was employed to know whether the variance of the data homogeneous or not. Based on the calculation it is obtained that $F_{\text {Ratio }}$ of pre and post test is lowest than $F_{\text {Table }}$ for the significance level of $5 \%$ $(\alpha=0,05)$ and $1 \%(\alpha=0,01)$. It means that both of samples in this research come from the population have the variance equality.

And then the researcher continued to find out the result of hypothesis. The object of the research is to know whether there is influence of Time Token method toward students' speaking ability. The researcher used t-test to prove the hypothesis proposed toward the result of post-test. Based on the calculation of post-test score and the result of criteria of the hypothesis on the table above, the result found that $t_{\text {Count }}=5,37$; moreover the researcher looked at $t_{\text {Table }}$ for the significant level $\alpha=1 \%$ showed $t_{\text {Table }}=2,66$ and for the significant level $\alpha=5 \%$

showed $t_{\text {Table }}=2,00$ or it means $t_{\text {Count }} \geq t_{\text {Table }}$.So, $\mathrm{H}_{\mathrm{o}}$ is rejected and $\mathrm{H}_{\mathrm{a}}$ is accepted. Based on the analyzing above, we knew that the students' speaking ability using Time Token method is higher than regular method. It also can be said that Time token method is more effective than regular method.

\section{DISCUSSION}

As describe in the previous chapter, the purpose of this study is to know the influence of using Time Token Method toward students' speaking ability, and to know is more effective toward the students' speaking ability between using 
Time Token method and regular method as a teacher method. To clarify the purpose of this study, the researcher used speaking test (which is used in the pretest and post-test) as a research instrument, and the average score of pre-test and post-test for each class using Time Token method in experiment class and regular method as a teachers 'in control class compare to find out the advantages of both score.

The results are consistence with the result of research Fatmawati (2011) entitled "The effectiveness of Time Token Arends Strategy Toward Reading Comprehension in Travelling Report in Eight Grade SMP N Wonosari Gunung Kidul". The previous research result was the Time Token Arends in increasing the students' achievement for students understand the reading comprehension SMP N Wonosari Gunung Kidul. The result of the study that based on the found data of her, the researcher analyzes some result finding, namely: The research findings show that Time Token can improve the students' speaking ability:

1) The students are motivated to achieve their initiative and participation.

2) The students do not dominate talk or silent absolutely.

3) The students could be more active in learning activity.

4) The students are able to achieve students' ability in communication.

5) The students are able to express their opinion.

6) The students are able to build students' habit for listening, sharing, giving opinion, and critic.

\section{CONCLUSION}

After the researcher finished the research and analyzed the data that obtained from the research, then some conclusion can be drawn. Based on the result of the research, the researcher draw the conclusion as follow: The students score of using Time Token method at the eighth grade is high, it supported by the result of $t_{\text {count }}=5,37$ is higher than $t_{\text {daf }}=2,66$ on the criterion $1 \%$. Besides, the other proof is the result of post test in experiment class is 80 . It shows that the students score of using Time Token method is high; The students score of speaking ability influenced by using Time Token method is high. It can be seen from $\mathrm{t}_{\text {count }}=5,37$ is higher than $\mathrm{t}_{\mathrm{daf}}=2,00$ on the criterion $5 \%$. So, the students score of speaking ability 
by using Time Token method is higher than the students score of speaking ability using regular method; The influence of using Time Token method toward students speaking ability is high. It can be seen from the result of the hypothesis testing. It shows that $t_{\text {count }}$ is 5,37 and $t_{\text {daf }}$ is 2,66 at the significant level 0,01 and $t_{\text {daf }} 2,00$ at the significant level 0,05 . It means that $t$ obtained is higher that $t_{\text {daf }}$.

Based on the conclution above, it shows that hypothesis of $\mathrm{H}_{\mathrm{a}}$ is accepted and $\mathrm{H}_{\mathrm{o}}$ is rejected. It supported by the result of the analysis research hypothesis. Hypothesis $\mathrm{H}_{\mathrm{a}}$ is accepted at the significant level of 0,05 and 0,01 with the result of $t_{\text {count }} 5,37$. It means that, there is positive influence of using Time Token method toward students speaking ability.

\section{RECOMMENDATION}

Based on the explanation above, the researcher will give some recommendation addressed to students, especially for English teacher.

1). Based on the data analysis, proved that Time Token method makes the students speaking ability better than before. To increase students ability in speaking, the researcher suggests the teacher to apply Time Token method in teaching speaking. Besides, it make the students feel self confident to speak English.

2). In applying the technique, the teachers have to follow the rules or steps correctly, so students won't be confused and the activity of learning will run well. The researcher also expects when the teachers use the technique in instructional, they must be careful in selecting the technique especially in speaking. Since the technique should be appropriate with the curriculum and also could encourage the students' ability in speaking.

\section{REFERENCES}

Agus, Suprijono, (2009).Cooperative Learning Teoridan Aplikasi PAIKEM. Yogyakarta PustakaPelajar.

Ahmad, Jazim (2011). Statistik Lanjut.Metro: FKIP UM Metro. 
Arends, Richard I. (2008). Learning to Teach. Yogyakarta:

PustakaPelajar.

Hughes in Fitriana. (2004). Speaking Ability. How to Improve English Speaking Ability. http: //www.ehow.com/how 5809059 improve-English-

Speaking-Ability.com/ retrieved on Monday, March 28 ${ }^{\text {th }}, 2011$ at $2.30 \mathrm{pm}$.

Hornby A. S. 1995. Oxford Learner's Dictionary of Current English. London: Oxford University Press.

Sugiyono, Prof.Dr. (2010).Metode Penelitian Pendidikan Pendekatan Kuantitatif, Kualitatif, dan R\&D.Bandung: Alfabeta.

Sugiyono (2013).MetodePenelitian Pendidikan: Pendekatan Kuantitatif,Kualitatif, dan $R \& D$. Bandung: Alfabeta

Yeni, Novi. (2011). “Keefektifan Strategi Time Token Arend terhadapKemampuan MenyimakLaporan PerjalananpadaSiswaKelas VIII SMP N I Wonosari Gunungkidul”.Yogyakarta 